\title{
Transforming Growth Factor- $\beta$ Increases Steady State Levels of Type I Procollagen and Fibronectin Messenger RNAs Posttranscriptionally in Cultured Human Dermal Fibroblasts
}

\author{
Rajendra Raghow, ${ }^{\star \ddagger}$ Amold E. Postlethwaite, ${ }^{\text {\$5 }}$ Jorma Keski-Oja," Harold L. Moses," and Andrew H. Kang \\ Departments of ${ }^{*}$ Pharmacology, 'Biochemistry, and ${ }^{\S}$ Medicine, University of Tennessee, Memphis, \\ ${ }^{\ddagger}$ Veterans Administration Medical Center, Memphis, Tennessee 38104; and "Department of Cell Biology, \\ Vanderbilt University School of Medicine, Nashville, Tennessee 37232
}

\begin{abstract}
Transforming growth factor- $\beta$ (TGF $\beta$ ), when injected subcutaneously into newborn mice, induces a rapid fibrotic response, stimulates chemotaxis, and elevates the rates of biosynthesis of collagen and fibronectin by fibroblasts in vitro. We explored the molecular mechanisms of TGF $\beta$-mediated stimulation of collagen and fibronectin synthesis in cultured human foreskin fibroblasts. TGF $\beta$ preferentially stimulated the synthesis of fibronectin and type I procollagen chains 3 -5-fold as shown by polypeptide analysis. Concomitant elevation in the steady state levels of messenger RNAs (mRNAs) coding for type I procollagen and fibronectin also occurred but without a net increase in the rate of transcription of either of these genes. The preferential stabilization of mRNAs specifying type I procollagen and fibronectin provides a partial explanation for the mechanisms by which TGF $\beta$ enhances the synthesis of type I procollagen and fibronectin in mesenchymal cells.
\end{abstract}

\section{Introduction}

Transforming growth factor $-\beta$ (TGF $\beta)^{1}$ is one of the two polypeptides (the other being TGF $\alpha$ ) that were originally characterized by their ability to reversibly induce the transformed phenotype in certain nontumorigenic cells (1-5). TGF $\alpha$ and TGF $\beta$ are structurally and antigenically distinct and have different cell surface receptors $(1,5-9)$. TGF $\beta$ has been recently molecularly cloned and is known to have a homodimeric structure with two disulfide-linked polypeptide chains of $12.5 \mathrm{kD}(1,6)$.

TGF $\beta$ is widely distributed in different tissues and cells including various tumors, $T$ cells, monocytes, and platelets $(2,7$, 10-12). Recently, it has been recognized that TGF $\beta$ is a potent desmoplastic agent. When injected subcutaneously into newborn mice, it causes a rapid increase in connective tissue formation

Address correspondence to Dr. Postlethwaite, Director, Division of Connective Tissue Diseases, U. of Tennessee, Memphis, College of Medicine, 956 Court Ave., Rm. G326, Memphis, TN 38163.

Received for publication 28 October 1986.

1. Abbreviation used in this paper: TGF $\beta$, transforming growth factor- $\beta$.

J. Clin. Invest.

(c) The American Society for Clinical Investigation, Inc.

$0021-9738 / 87 / 04 / 1285 / 04 \$ 1.00$

Volume 79, April 1987, 1285-1288
(10). TGF $\beta$ is capable of stimulating fibroblast chemotaxis and production of collagen and fibronectin (10-13); the mechanisms by which it exerts these effects are unclear. We report here that TGF $\beta$ acts on human dermal fibroblasts at the pretranslational level by stimulating the accumulation of fibronectin and type I procollagen messenger RNAs (mRNAs).

\section{Methods}

Materials. Eagle's minimum essential medium (supplemented with nonessential amino acids, ascorbic acid, amphotericin $\mathrm{B}, \mathrm{NaHCO}_{3}$, penicillin, and streptomycin), fetal calf serum, and phosphate-buffered saline (PBS) were purchased from Gibco, Grand Island, NY. Radiochemicals' $\left[{ }^{14} \mathrm{C}\right]$ acetic anhydride $(8.9 \mathrm{mCi} / \mathrm{mmol}, \mathrm{sp}$ act $),\left[{ }^{35} \mathrm{~S}\right]$ methionine $(>1,200$ $\mathrm{Ci} / \mathrm{mmol}$, sp act), $\left[{ }^{3} \mathrm{H}\right]$ proline $(20 \mathrm{Ci} / \mathrm{mmol}, \mathrm{sp}$ act $),\left[{ }^{32} \mathrm{P}\right] \mathrm{dCTP}(3,000$ $\mathrm{Ci} / \mathrm{mmol}$, sp act), $\mathrm{EN}^{3} \mathrm{HANCE}$, and Aquasol were purchased from New England Nuclear, Boston, MA.

Fibroblast cultures. Human fibroblast cultures were established from explants of infant foreskins by standard techniques. Cells were grown in 100-mm diam Petri dishes in Eagle's medium supplemented with $10 \%$ fetal calf serum. The cultures were routinely passaged every $3-5 \mathrm{~d}$.

$T G F \beta$. TGF $\beta$ was purified from homogenates of outdated human platelets by techniques developed in our laboratory (H. L. Moses) and published in detail elsewhere $(1,7,8)$. The purity of the TGF $\beta$ preparations used in this study was monitored by polypeptide analysis using silver staining of sodium dodecyl sulfate (SDS) polyacrylamide gels (1). All preparations used contained only a $25-\mathrm{kD}$ protein band on the gels, which was reduced to a $12.5-\mathrm{kD}$ band by 2 -mercaptoethanol (1). The biological activity of TGF $\beta$ was tested by radioreceptor and soft agar colony formation assays using AKR-2B cells (clone 84A) and growth inhibition assays using A549 indicator cells. All preparations used were active at nanograms per milliliter concentrations $(1,4,8)$.

Quantitation of collagenous and noncollagenous protein synthesis. Fibroblasts were seeded in wells of Falcon 3008 multiwell plates $\left(5 \times 10^{4}\right.$ cells $/ 0.5 \mathrm{ml}$ maintenance medium). Triplicate wells of confluent monolayers were incubated in fresh serum-free medium (minus nonessential amino acids) supplemented with either PBS or TGF $\beta$ (50 $\mu \mathrm{l}$ vol). Supernatants from each well were harvested $24 \mathrm{~h}$ later and assayed for the levels of collagenase-sensitive proteins according to a previously published method (14). Alternatively, confluent fibroblasts (100-mm diam Petri dishes) were treated with either PBS or TGF $\beta(2.5 \mathrm{ng} / \mathrm{ml})$ for $24 \mathrm{~h}$ and labeled with either $\left[{ }^{35} \mathrm{~S}\right]$ methionine $(25 \mu \mathrm{Ci} / \mathrm{ml})$ or $\left[{ }^{3} \mathrm{H}\right]$ proline $(50 \mu \mathrm{Ci} /$ $\mathrm{ml})$. The radiolabeled proteins were processed according to previously published protocols and analyzed by SDS-polyacrylamide gel electrophoresis (PAGE) (15-17). The fluorograms were scanned on a LKB laser densitometer coupled with a Hewlett-Packard 3390A integrator. The rates of total protein synthesis were quantitated by labeling the cells with $\left[{ }^{35} \mathrm{~S}\right]$ methionine in methionine-free media as described in detail previously (15-17). 
Quantitative analysis of $m R N A s$ and rates of transcription. Total cellular RNA was extracted by guanidine thiocyanate solubilization of cells and centrifugation of the extract through a cushion of $5.7 \mathrm{M} \mathrm{CsCl}$. RNA was heat denatured in formamide and electrophoresed in $1 \%$ agarose gels containing $2.2 \mathrm{M}$ formaldehyde. After electrophoresis, the RNA samples were transferred to a nitrocellulose sheet, dried, baked at $80^{\circ} \mathrm{C}$ under vacuum and subjected to Northern analysis. Radiolabeled nicktranslated recombinant RNA plasmids $\left(1-5 \times 10^{7} \mathrm{cpm} / \mu \mathrm{g}\right.$, sp act) were hybridized under conditions of excess probe. After removing the probe, the blots were subjected to another round of prehybridization and hybridization with a second probe. Detailed protocols for the extraction and quantitation by Northern analyses of $\alpha \mathrm{l}$ (I) procollagen, fibronectin, and $\beta$-actin mRNAs using recombinant complementary DNA (cDNA) probes have been described previously $(15,16)$.

Previously published techniques were used for the isolation of nuclei, in vitro transcription, and subsequent determination of the rates of transcription by hybridization (16). Nuclei from control or TGF $\beta$-treated cells $(100-150 \mu \mathrm{g}$ of DNA) were incubated in a $100 \mu \mathrm{l}$ reaction mixture that contained $10 \%$ glycerol, $50 \mathrm{mM}$ Tris- $\mathrm{HCl}, \mathrm{pH} 8.0,5 \mathrm{mM} \mathrm{MgCl}_{2}$, $1 \mathrm{mM}$ each ATP, GTP, and CTP, and $250 \mu \mathrm{Ci}$ of $\left[\alpha^{32} \mathrm{P}\right] \mathrm{UTP}$ at $25^{\circ} \mathrm{C}$ for $30 \mathrm{~min}$. Radiolabeled RNA was extracted and hybridized to DNA immobilized on nitrocellulose filters. In each case, $5 \mu \mathrm{g}$ of linearized, alkali-denatured, plasmid DNA was immobilized on nitrocellulose filter using a slot-blot apparatus. For determining nonspecific background, 5 $\mu \mathrm{g}$ each of pBR322 and bacteriophage $\lambda$ Charon 4A DNA were separately hybridized with radiolabeled run-off transcripts. Nitrocellulose filters were baked as described above, prehybridized, and hybridized at $42^{\circ} \mathrm{C}$ for 24 and $48 \mathrm{~h}$, respectively. These hybridizations were done under conditions of DNA excess; hybridization for longer than $24 \mathrm{~h}$ did not result in increased signal intensity, and therefore we believe that maximum hybridization was achieved under these conditions.

\section{Results}

Effect of TGF $\beta$ on collagen synthesis. Purified human plateletderived TGF $\beta$ stimulated production of collagen by dermal fibroblasts in a dose-dependent manner (Fig. 1). A dose of 2.5 $\mathrm{ng} / \mathrm{ml}$ was used in studies to assess the effect of TGF $\beta$ on the rates of procollagen and fibronectin synthesis by pulse-labeling cells with either $\left[{ }^{3} \mathrm{H}\right]$ proline or $\left[{ }^{35} \mathrm{~S}\right]$ methionine. Radiolabeled polypeptides released into the medium as well as cell-associated polypeptides were analyzed by SDS-PAGE and fluorographed (Fig. 2). As judged by densitometric quantitation of the fluorogram representing $\left[{ }^{3} \mathrm{H}\right]$ proline-labeled soluble polypeptides from the medium, a 24-h treatment with TGF $\beta$ caused approximately a fourfold stimulation in the amounts of type I procollagen chains produced by fibroblasts over control; there was also a 2-3-fold stimulation in the rate of fibronectin synthesis by TGF $\beta$ (Table I). The effect on the synthesis of type I procollagen

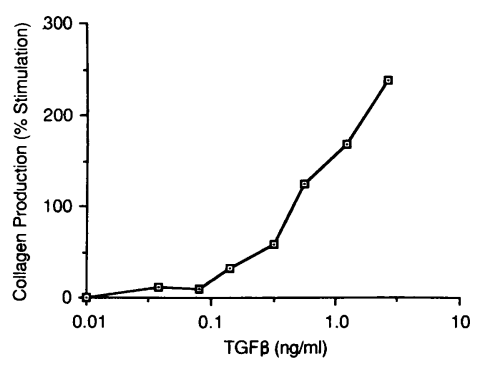

Figure 1. TGF $\beta$ elevates the rate of collagen biosynthesis in a dose-dependent manner. Fibroblasts in confluent monolayer cultures were grown in the presence of PBS or denoted concentrations of TGF $\beta(0.01-10 \mathrm{ng}$ $\mathrm{ml}$ ) for $24 \mathrm{~h}$ and labeled with $\left[{ }^{3} \mathrm{H}\right]$ proline $(10 \mu \mathrm{Ci} /$ $\mathrm{ml})$. The amounts of collagenase-sensitive proteins in the culture medium were determined as described in Methods. The amount of collagenase-sensitive radioactivity in the control cultures was $2,206 \pm 210 \mathrm{cpm}$, and the standard error of the mean for each of the triplicates was $<15 \%$.

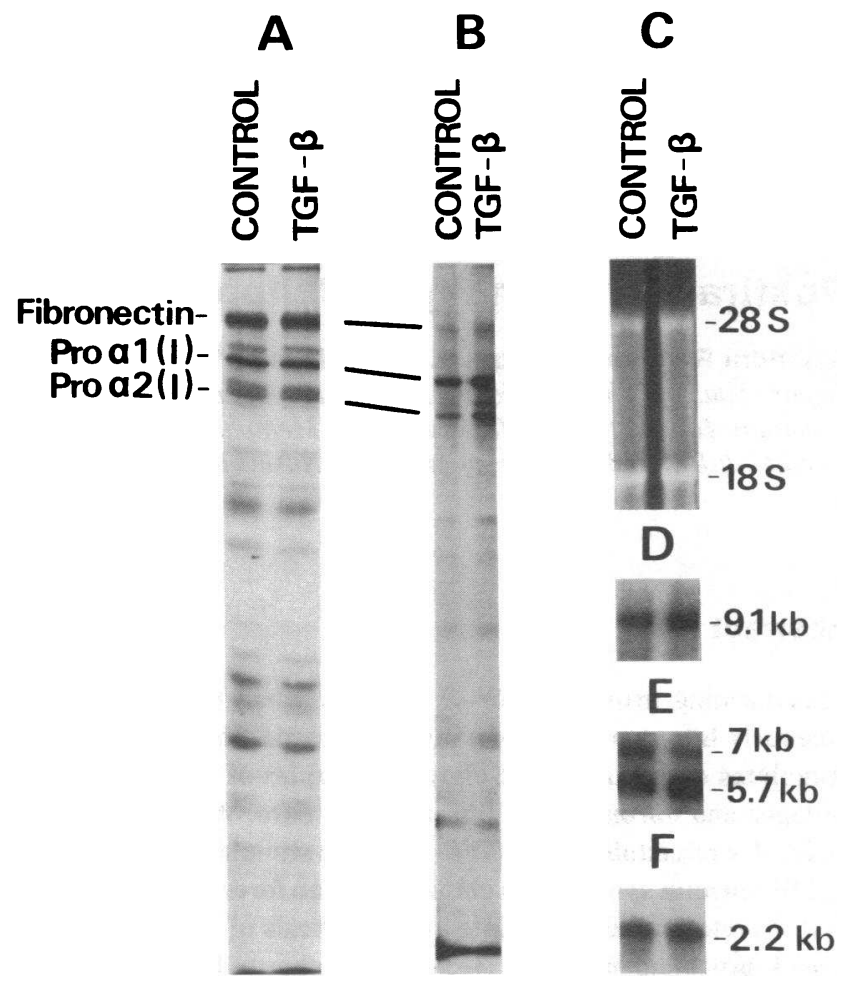

Figure 2. TGF $\beta$ selectively increases the rates of synthesis of type I procollagen and fibronectin and the steady state accumulation of their cognate mRNAs. Fibroblast cultures were treated with TGF $\beta(2.5 \mathrm{ng} /$ $\mathrm{ml}$ ) for $24 \mathrm{~h}$; cells were subsequently labeled with either

$\left[{ }^{35} \mathrm{~S}\right]$ methionine or $\left[{ }^{3} \mathrm{H}\right]$ proline for $4 \mathrm{~h}$ and the cell-associated or extracellularly released polypeptides were analyzed by $7.5 \%$ SDS-PAGE followed by fluorography. mRNA for parallel cultures was subjected to northern hybridization using cDNA plasmids containing fibronectin, pro $\alpha 1(\mathrm{I})$, and $\beta$-actin sequences as described in the Methods section. $(A)$ Cell-associated polypeptides labeled with $\left[{ }^{35} S\right]$ methionine; $(B)$ Extracellular polypeptides labeled with $\left[{ }^{3} \mathrm{H}\right]$ proline; $(C)$ Ethidium bromide-stained gel representing $10 \mu \mathrm{g}$ of total RNA; $(D)$ Northern blot hybridized to fibronectin cDNA; $(E)$ mRNA probed with a cDNA containing pro $\alpha 1(\mathrm{I})$ sequences; and $(F) \beta$-actin mRNA.

Table I. Quantification of Total Protein, Procollagen Type I, and Fibronectin Synthesis in TGFR-treated Fibroblasts*

\begin{tabular}{llll}
\hline Proteins & Control & TGF $\beta$ & $\begin{array}{l}\text { Fold } \\
\text { stimulation }\end{array}$ \\
\hline Total $^{\ddagger}$ & $\begin{array}{l}4.8 \times 10^{6} \\
\mathrm{cpm} / \mathrm{mg} \mathrm{DNA}\end{array}$ & $\begin{array}{c}6.2 \times 10^{6} \\
\mathrm{cpm} / \mathrm{mg} \mathrm{DNA}\end{array}$ & 1.3 \\
& 1.89 & 7.86 & \\
Pro $\alpha 1(\mathrm{I})^{8}$ & 0.62 & 2.27 & 4.2 \\
Pro $\alpha 2\left(\mathrm{I}^{8}\right.$ & 0.51 & 1.63 & 3.7 \\
Fibronectin & & & 3.2
\end{tabular}

* Confluent monolayers of fibroblasts exposed to PBS or TGF $\beta$ were cultured for $24 \mathrm{~h}$ at which time $\left[{ }^{35} \mathrm{~S}\right]$ methionine or $\left[{ }^{3} \mathrm{H}\right]$ proline was added to the media and incubation for 4 more hours continued. The radiolabeled proteins representing either cell-associated or extracellularly released fractions were processed and analyzed by SDS-PAGE as described in Methods.

₹ Calculated from the incorporation of $\left[{ }^{35} \mathrm{~S}\right]$ methionine into trichloroacetic acid (10\%) insoluble peptides.

- Calculated from the densitometric scan of a fluorogram representing $\left[{ }^{3} \mathrm{H}\right]$ proline-labeled polypeptides released into the medium. 
chains and fibronectin appeared to be preferential, since the total incorporation of $\left[{ }^{35} \mathrm{~S}\right]$ methionine into cellular polypeptides was affected to a much lesser extent (Fig. 2; Table I). Although TGF $\beta$ consistently stimulated the rate of collagen and fibronectin synthesis, there was considerable variation from experiment to experiment; 2-7-fold stimulation in the rates of synthesis of these polypeptides were observed (data not shown). The reasons for this variation are not entirely clear at the present time and therefore it remains a subject of much speculation (see Discussion).

Stimulation in the steady state accumulation of type I procollagen and fibronectin $m R N A s$. To determine whether the increased collagen synthesis in TGF $\beta$-treated cells was reflected in the steady state levels of their corresponding mRNAs, we extracted the total RNA from fibroblasts $24 \mathrm{~h}$ after TGF $\beta$ treatment. An equal amount of total RNA, the ethidium bromide staining pattern of which is shown in Fig. 2, was transferred to nitrocellulose filters and probed with nick-translated cDNA plasmids specific for pro $\alpha 1(\mathrm{I})$, fibronectin, and cytoplasmic $\beta$ actin. Densitometric analysis of the autoradiograms (Fig. 2, D$F$ ) showed that TGF $\beta$ caused a 2-3-fold increase in the steady state levels of fibronectin and pro $\alpha 1$ (I) mRNAs (densitometric scanning data not presented). The effect of TGF $\beta$ on the mRNAs for type I procollagen and fibronectin appeared to be selective, since the levels of $\beta$-actin mRNAs in TGF $\beta$-treated cells were affected only minimally (Fig. $2, D-F$ ). The variability from culture to culture noted in the rates of individual polypeptide synthesis was also apparent in the steady state levels of various mRNAs. For example, in another experiment, the level of $\beta$ actin mRNA was elevated 2-4-fold in the TGF $\beta$-treated cells, which accompanied a correspondingly greater accumulation (78-fold) in the steady state levels of fibronectin and pro $\alpha 1(\mathrm{I})$ collagen mRNAs (data not shown). Therefore, the selectivity of the effect of TGF $\beta$ on the type I collagen and fibronectin mRNAs was consistently maintained.

To seek an explanation for elevated accumulation of mRNAs for the two extracellular matrix proteins, we isolated nuclei from control and TGF $\beta$-treated fibroblasts and subjected these to runoff transcription. The autoradiogram in Fig. 3 shows the hybridization of run-off transcripts to pro $\alpha 1(I)$, fibronectin, and $\beta$-actin cDNA plasmids. The rate of transcription of the pro $\alpha 1(\mathrm{I})$, fibronectin, and $\beta$-actin genes did not change in TGF $\beta$ treated cells as evident from the visual inspection of the autoradiograms (Fig. 3). The densitometric quantitation of these autoradiographs essentially corroborated the visual impression (data not shown). We conclude, therefore, that the increased steady state levels of procollagen and fibronectin mRNAs probably did not involve a significant change in the rates of transcription of these genes.

\section{Discussion}

The biosynthesis of collagen and fibronectin can be potentially regulated at a number of transcriptional and posttranscriptional steps. Both positive and negative regulation has been shown to take place depending on the inducer (11, 13-24). For example, cortisol and other antiinflammatory steroids, parathyroid hormone, and $\boldsymbol{\gamma}$-interferon all cause a specific decrease in the cellular concentration of translatable type I procollagen mRNA $(16,18$, $19,24)$ by mechanisms that are poorly defined. Transformation of cultured fibroblasts with tumor viruses or carcinogens leads to a marked reduction in the rate of transcription of collagen

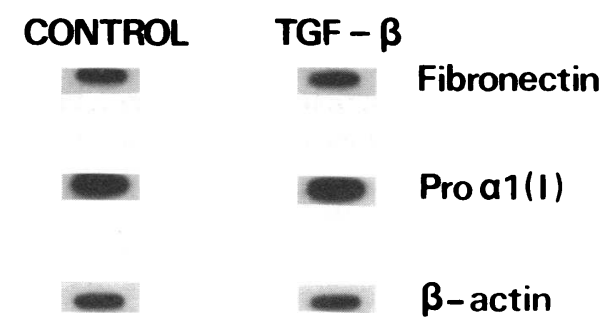

Figure 3. The rates of type I procollagen and fibronectin gene transcription remain unaltered after treatment with TGF $\beta$. Radiolabeled nuclear run-off transcripts from nuclei of control and TGF $\beta$-treated $(2.5 \mathrm{ng} / \mathrm{ml} ; 24 \mathrm{~h}$ after treatment) cells were hybridized to cDNA plasmids containing fibronectin, pro $\alpha 1$ (I), and $\beta$-actin sequences immobilized on nitrocellulose filter. Autoradiograms of the filters are shown. The detailed description of these protocols is in the Methods section.

genes with a consequent decrease in the levels of type I procollagen mRNAs (20-23). In contrast, a hepatic fibrogenic factor stimulates collagen production by increasing levels of various procollagen mRNAs (15).

Consistent with previous observations $(10,11,13)$, fibronectin and type I collagen biosynthesis by fibroblasts is significantly increased by TGF $\beta$. Elevated levels of type I procollagen and fibronectin mRNAs must, however, result from mechanisms other than transcription, since there is no measurable change in the rate of transcription of these genes after treatment with TGF $\beta$. We believe that the treatment with TGF $\beta$ selectively stabilizes the mRNAs for type I procollagen and fibronectin. However, until a direct demonstration of the relative rates of mRNA turnover is experimentally accomplished, the mechanism involving the preferential stabilization of type I procollagen and fibronectin mRNAs would remain tentative. Changes in the rates of $m$ RNA turnover have been shown to mediate the levels of gene expression in a number of different systems $(15,25,26)$. The precise mechanisms of preferential mRNA stabilization are incompletely understood (25).

The effect of TGF $\beta$ on $\beta$ - and $\gamma$-actin mRNA levels in mouse AKR-2B cells has been examined in detail in an earlier study (27). In AKR-2B fibroblasts, TGF $\beta(1-3 \mathrm{ng} / \mathrm{ml})$ stimulated the accumulation of actin mRNA (27). Maximal elevations of $\beta$ and $\gamma$-actin mRNAs occurred 4-8 h after the addition of TGF $\beta$ to the confluent, quiescent cultures of AKR-2B cells; by $24 \mathrm{~h}$, the levels of actin mRNA were lower than at 4-8 h posttreatment with TGF $\beta$ (27). TGF $\beta$ also caused the murine AKR-2B cells to undergo striking morphologic changes $24 \mathrm{~h}$ after exposure (27). In contrast, human fibroblasts do not undergo such morphologic changes in response to TGF $\beta$ but are stimulated to divide, produce increased quantities of collagen and fibronectin, and chemotax (1, 10-14). Since $\beta$ - and $\alpha$-actins are major structural proteins of cellular microfilaments, they are considered to be involved in cell motility, mitosis, and morphogenesis. The underlying reasons for the variable effect of TGF $\beta$ on the levels of actin mRNA in some cells and not in others remain incompletely understood.

The final point concerns the wide variability in the biological and biochemical responses of various cell types to the effects of TGF $\beta$. While TGF $\beta$ generally promotes mitogenesis in the mesenchymal cells (1), the growth of several other types of cells is clearly inhibited by this factor $(1,28-31)$. The precise biochemical mechanisms that underlie such disparate actions of TGF $\beta$ are incompletely understood. Nonetreless, the overall effects of 
this factor on mesenchymal cells, which include increased synthesis and deposition of extracellular matrix proteins, increased chemotaxis and proliferation, suggest that TGF $\beta$ may be an important modulator of postinflammatory tissue regeneration.

\section{Acknowledgments}

The excellent technical assistance of William Jeffries and Dey Pidikiti is acknowledged. We also thank Phyllis Mikula and Joan Smith for typing the manuscript.

This work was supported by grants AM-16506, AM-26034, and CA42572 from National Institutes of Health, and by research funds from the Veterans Administration.

\section{References}

1. Moses, H. L., R. F. Tucker, E. B. Leof, R. J. Coffey, Jr., J. Halper, and G. D. Shipley. 1985. Type- $\beta$ transforming growth factor in a growth stimulator and a growth inhibitor. In Cancer Cells, Vol. 3. J. Feramisco, B. Ozanne, and C. Stiles, editors. Cold Spring Harbor Press, New York. 65-71.

2. Keski-Oja, J., E. B. Leof, R. M. Lyons, R. J. Coffey, Jr., and H. L. Moses. 1987. Transforming growth factors and control of neoplastic cell growth. J. Cell. Biochem. 33:95-107.

3. Roberts, A. B., M. A. Anzano, L. C. Lamb, J. M. Smith, and M. B. Sporn. 1981. New class of transforming growth factors potentiated by epidermal growth factor: isolation from non-neoplastic tissues. Proc. Natl. Acad. Sci. USA. 78:5339-5343.

4. Moses, H. L., E. B. Branum, J. A. Proper, and R. A. Robinson. 1981. Transforming growth factor production by chemically transformed cells. Cancer Res. 41:2842-2848.

5. Anzano, M. A., A. B. Roberts, J. M. Smith, M. B. Sporn, and J. E. DeLarco. 1983. Sarcoma growth factor from conditioned medium of virally transformed cells is composed of both type- $\alpha$ and type- $\beta$ transforming growth factors. Proc. Natl. Acad. Sci. USA. 80:6264-6268.

6. Dernyck, R., J. A. Jarrett, Y. Chen, D. H. Eaton, J. R. Bell, R. K. Assoian, A. B. Roberts, M. B. Sporn, and D. V. Goeddel. 1985. Human transforming growth factor- $\beta$ cDNA sequence and expression in tumor cell lines. Nature (Lond.). 316:701-705.

7. Assoian, R. K., C. A. Komoriya, D. M. Meyers, D. M. Miller, and M. B. Sporn. 1983. Transforming growth factor- $\beta$ in human platelets: identification of major storage site, purification and characterization. $J$. Biol. Chem. 258:7155-7160.

8. Tucker, R. F., E. L. Branum, G. D. Shipley, R. J. Ryan, and H. L. Moses. 1984. Specific binding to cultured cells of ${ }^{125}$ I-labeled type$\beta$ transforming growth factor from human platelets. Proc. Natl. Acad. Sci. USA. 81:6757-6761.

9. Cheifetz, S., B. Like, and J. Massagué. 1986. Cellular distribution of type I and type II receptors for transforming growth factor- $\beta$. J. Biol. Chem. 261:9972-9978.

10. Roberts, A. B., M. B. Sporn, R. K. Assoian, J. M. Smith, N. S. Roche, L. M. Wakefield, U. I. Heine, L. A. Liotta, V. A. Falanga, J. H. Kehrl, and A. S. Fauci. 1986. Transforming growth factor type- $\beta$ : rapid induction of fibrosis and angiogenesis in vivo and stimulation of collagen formation in vitro. Proc. Natl. Acad. Sci. USA. 83:4167-4171.

11. Ignotz, R. A., and J. Massagué. 1986. Transforming growth factor$\beta$ stimulates the expression of fibronectin and collagen and their incorporation into the extracellular matrix. J. Biol. Chem. 261:4337-4342.

12. Postlethwaite, A. E., J. Keski-Oja, H. L. Moses, and A. H. Kang. 1987. Stimulation of the chemotactic migration of human fibroblasts by transforming growth factor- $\beta$. J. Exp. Med. 165:251-256.

13. Varga, J., and S. A. Jimenez. 1986. Stimulation of normal human fibroblast collagen production and processing by transforming growth factor- $\beta$. Biochem. Biophys. Res. Commun. 138:974-980.

14. Postlethwaite, A. E., G. N. Smith, C. L. Mainardi, J. M. Seyer, and A. H. Kang. 1984. Lymphocyte modulation of fibroblasts in vitro: stimulation and inhibition of collagen production by different effector molecules. J. Immunol. 132:2470-2477.

15. Raghow, R., D. Gossage, J. M. Seyer, and A. H. Kang. 1984. Transcriptional regulation of type I collagen genes in cultured fibroblasts by a factor isolated from thioacetamide-induced fibrotic rat liver. J. Biol. Chem. 259:12718-12723.

16. Raghow, R., D. Gossage, and A. H. Kang. 1986. Pretranslational regulation of type I procollagen, fibronectin and a 50 kilodalton noncollagenous extracellular matrix protein by dexamethasone in rat fibroblasts. J. Biol. Chem. 261:4677-4684.

17. Aycock, R. S., R. Raghow, G. P. Stricklin, J. M. Seyer, and A. H. Kang. 1986. Post-transcriptional inhibition of collagen and fibronectin synthesis by a synthetic homolog of a portion of the carboxyl terminal propeptide of human type I collagen. J. Biol. Chem. 261:1433514360.

18. Oikarinen, J., and L. Ryhänen. 1981. Cortisol decreases the concentration of translatable type I procollagen mRNA species in the developing chick-embryo calvaria. Biochem. J. 198:519-524.

19. Kream, B. E., D. W. Rowe, S. L. Gworek, and L. G. Ritz. 1980. Parathyroid hormone alters collagen synthesis and procollagen mRNA levels in fetal rat calvaria. Proc. Natl. Acad. Sci. USA. 77:5654-5658.

20. Adams, S. L., J. L. Alwine, B. deCrombrugghe, and I. Pastan. 1979. Use of recombinant plasmids to characterize collagen RNAs in normal and transformed chick embryo fibroblasts. J. Biol. Chem. 254: 4935-4938.

21. Prockop, D. J., K. I. Kivirikko, L. Tuderman, and N. A. Guzman. 1979. The biosynthesis of collagen and its disorders. N. Engl. J. Med. 301:13-23, 77-85.

22. Sandmeyer, S., and P. Bornstein. 1979. Declining procollagen mRNA sequences in chick embryo fibroblasts infected with Rous sarcoma virus. Correlation with procollagen synthesis. J. Biol. Chem. 254:49504953.

23. Sandmeyer, S., R. Smith, D. Kiehn, and P. Bornstein. 1981. Correlation of collagen synthesis and procollagen messenger RNA levels with transformation in rat embryo fibroblasts. Cancer Res. 41:830-838.

24. Jimenez, S. A., B. Freundlich, and J. Rosenbloom. 1984. Selective inhibition of human diploid fibroblast collagen synthesis by interferon. J. Clin. Invest. 74:1112-1116.

25. Shaw, G. and R. Kamen, 1986. A conserved AU sequence from 3'-untranslated region of GM-CSF mRNA mediates selective mRNA degradation. Cell 46:659-667.

26. Sittman, D. B., R. A. Graves, and W. F. Marzluff. 1983. Histone mRNA concentrations are regulated at the level of transcription and mRNA degradation. Proc. Natl. Acad. Sci. USA. 80:1849-1853.

27. Leof, E. B., J. A. Proper, M. J. Getz, and H. L. Moses. 1986. Transforming growth factor type- $\beta$ regulation of actin mRNA. J. Cell. Physiol. 127:83-88.

28. Roberts, A. B., M. A. Anzano, L. M. Wakefield, N. S. Roche, D. F. Stern, and M. B. Sporn. 1985. Type $\beta$ transforming growth factor: a bifunctional regulator of cellular growth. Proc. Natl. Acad. Sci. USA. 82:119-123.

29. Shipley, G. D., M. R. Pittlekow, J. J. Willie, R. E. Scott, and H. L. Moses. 1986. Reversible inhibition of normal human prokeratinocyte proliferation by type- $\beta$ transforming growth factor-growth inhibitor in serum-free medium. Cancer Res. 46:2068-2071.

30. Like, B., and J. Massagué. 1986. The antiproliferative effect of type- $\beta$ transforming growth factor occurs at a level distal from receptors for growth activating factors. J. Biol. Chem. 261:13426-13429.

31. Massagué, J., S. Cheifetz, T. Endo, and B. Nadal-Ginard. 1986. Type $\beta$ transforming growth factor is an inhibitor of myogenic differentiation. Proc. Natl. Acad. Sci. USA. 83:8206-8210. 